\title{
Maintenance requirements for energy in cross-bred cattle*
}

\author{
By B. R. PATLE† AND V. D. MUDGAL \\ National Dairy Research Institute, Karnal (Haryana), India \\ (Received 29 fanuary 1974 - Accepted 7 May 1974)
}

\begin{abstract}
I. Twenty-seven energy and protein balances were done using nine cross-bred (Brown Swiss $\times$ Sahiwal) mature bullocks in a series of three balance trials. The bullocks were fed 75,100 and $125 \%$ of the metabolizable energy $(\mathrm{ME})$ and digestible crude protein standard values recommended by the (US) National Research Council (I966). Heat production was estimated by indirect calorimetry, by collection and analysis of respiratory gases.

2. Utilization of energy for maintenance and fat production was estimated by computing regression of energy balance $v$. digestible energy (DE) and ME separately on a metabolic body size (kg body-weight $(\mathrm{W})^{0.75}$ ) basis. Maintenance energy requirements and efficiency of utilization of ME for lipogenesis were estimated using multiple regression of ME intake, also. Heat production (and thus energy balance) was corrected for excess nitrogen intake.

3. An attempt was made to measure basal heat production of bullocks so that the net energy requirements for maintenance could be estimated. Extrapolation of the regression line of energy balance $v$. ME intake below maintenance on a $\mathrm{W}^{0.75}$ basis gave a basal metabolism of $348 \cdot 09 \mathrm{~kJ} / \mathrm{W}^{0} \cdot 75$ per d.

4. Energy requirements for maintenance were $\left(\mathrm{kJ} / \mathrm{kg} \mathrm{W} \mathrm{W}^{0 \cdot 75}\right.$ per d): $539^{\circ} 43 \mathrm{DE}, 44^{8} \cdot 8 \mathrm{I} \mathrm{ME}$ and 348.09 net energy. The results of multiple regression gave a requirement of $432 \cdot 15 \mathrm{~kJ} \mathrm{ME} / \mathrm{kg}$ $\mathrm{W}^{0 \cdot 75}$ per $\mathrm{d}$ for maintenance.

5. The efficiency of utilization of ME for maintenance was $8 \mathrm{r} \cdot 34 \%$ while for lipogenesis it was $54.5 \%$.
\end{abstract}

The feeding standards at present used in India (Sen \& Ray, I964) are the same as those evolved in temperate countries, although the results of work carried out in India on nutrient requirements of Indian breeds of cattle (Mullick \& Kehar, I952, 1959; Mullick, I959a, $b$; Mudgal, I963, I969; Gopal Krishna, 1971) have suggested that the energy requirements for these animals are different from those recommended as the standard feeding values. With the launching of a cross-breeding programme, more high-producing cows are being bred for which the feeding standards for economic and optimum milk production are yet to be estimated. At present no systematic results are available on nutrient requirements of these cattle. Energy requirements for maintenance are of fundamental importance in correct feeding of any animals.

\section{EXPERIMENTAL}

\section{Design of experiment}

Nine cross-bred bullocks (Brown Swiss $\times$ Sahiwal), castrated at $1 \cdot 5$ years and ranging in age from 4 years 4 months to 5 years 5 months, were selected and were divided into heavy-, medium- and low-weight groups of three bullocks each. From these three groups one heavy-, one medium- and one low-weight bullock was

* National Dairy Research Institute Publication No. 74-18; taken from the PhD Thesis of the senior author (B.R.P.) submitted to Punjab University, Chandigarh, India.

$\dagger$ Present address: Associate Professor (Animal Nutrition), College of Veterinary Science and Animal Husbandry, JNKVV-Jabalpur, India. 
Table I. Experimental design and details of the bullocks used in the balance trials

\begin{tabular}{|c|c|c|c|c|c|}
\hline \multirow[b]{2}{*}{$\begin{array}{c}\text { Animal } \\
\text { no. }\end{array}$} & \multirow[b]{2}{*}{$\begin{array}{l}\text { Date of } \\
\text { birth }\end{array}$} & \multirow[b]{2}{*}{$\begin{array}{l}\text { Live weight } \\
\text { at start of } \\
\text { experiment }(\mathrm{kg})\end{array}$} & \multicolumn{3}{|c|}{ Energy levels } \\
\hline & & & $\begin{array}{c}\text { Period I* } \\
\text { (January-February } \\
\text { I970) }\end{array}$ & $\begin{array}{c}\text { Period 2* } \\
\text { (February-March } \\
\text { I970) }\end{array}$ & $\begin{array}{c}\text { Period 3* } \\
\text { (March-April } \\
\text { 1970) }\end{array}$ \\
\hline \multicolumn{6}{|c|}{ Low-protein (LP) group $\dagger$} \\
\hline $\begin{array}{l}57 \\
74 \\
72\end{array}$ & $\begin{array}{r}\text { 21 July I } 965 \\
3 \text { July I } 966 \\
7 \text { May I } 966\end{array}$ & $\begin{array}{l}538 \\
460 \\
428\end{array}$ & $\begin{array}{l}\text { ME } \\
\mathrm{HE} \\
\mathrm{LE}\end{array}$ & $\begin{array}{l}\text { HE } \\
\text { LE } \\
\text { ME }\end{array}$ & $\begin{array}{l}\text { LE } \\
M E \\
\mathrm{HE}\end{array}$ \\
\hline \multicolumn{6}{|c|}{ Medium-protein (MP) group $\dagger$} \\
\hline $\begin{array}{l}60 \\
59 \\
83\end{array}$ & $\begin{array}{l}\text { 30 July I } 965 \\
28 \text { July } 1965 \\
23 \text { August } 1966\end{array}$ & $\begin{array}{l}590 \\
515 \\
376\end{array}$ & $\begin{array}{l}\text { LE } \\
\mathrm{HE} \\
\mathrm{ME}\end{array}$ & $\begin{array}{l}\text { ME } \\
\text { LE } \\
\text { HE }\end{array}$ & $\begin{array}{l}\mathrm{HE} \\
\mathrm{ME} \\
\mathrm{LE}\end{array}$ \\
\hline \multicolumn{6}{|c|}{ High-protein (HP) group $\dagger$} \\
\hline $\begin{array}{l}14 \\
70 \\
69\end{array}$ & $\begin{array}{l}\text { 12 February } 1964 \\
\text { 17 March 1966 } \\
9 \text { May 1 } 966\end{array}$ & $\begin{array}{l}548 \\
464 \\
464\end{array}$ & $\begin{array}{l}\mathrm{LE} \\
\mathrm{HE} \\
\mathrm{ME}\end{array}$ & $\begin{array}{l}\text { HE } \\
\text { ME } \\
\text { LE }\end{array}$ & $\begin{array}{l}\text { ME } \\
\text { LE } \\
\text { HE }\end{array}$ \\
\hline
\end{tabular}

LE, ME and HE represent 75, I00 and $125 \%$ of the (US) National Research Council (Ig66) metabolizable energy requirements for maintenance.

* Each period included $7 \mathrm{~d}$ adjustment, $2 \mathrm{I} \mathrm{d}$ preliminary, $7 \mathrm{~d}$ collection and $9 \mathrm{~d}$ respiration periods.

+ LP, MP and HP represent 75, 100 and $125 \%$ of the (US) National Research Council (1966) digestible crude protein requirements for maintenance.

randomly selected to constitute one protein group. The three groups of bullocks thus formed were called low-, medium- and high-protein groups. The experimental design was in three $3 \times 3$ Latin squares with three bullocks and three levels of energy intake for each level of protein intake. The three levels of protein intake and three levels of energy intake used were 75,100 and $125 \%$ of the digestible crude protein and metabolizable energy (ME) standards for maintenance recommended by the (US) National Research Council (1966). The 75, 100 and 125\% digestible crude protein levels were termed LP, MP and HP levels and the 75, 100 and $125 \% \mathrm{ME}$ levels were termed LE, ME and HE levels. The details of the animals and the experimental design are shown in Table $\mathrm{I}$.

Each experimental period was preceded by a $7 \mathrm{~d}$ adjustment period during which all animals were fed according to (US) National Research Council (I966) standards. The experimental period consisted of $7 \mathrm{~d}$ adjustment, 21 d preliminary, $7 \mathrm{~d}$ collection and $9 \mathrm{~d}$ respiration periods. During the 'collection' period, a total collection of faeces and urine was made. During the 'respiration' period the heat production was measured by indirect calorimetry using Douglas bags for collection of respiratory gases which were analysed using the Haldane gas analysis apparatus. Energy balances were calculated by subtracting heat production from ME intake. A total of twentyseven energy balance determinations were completed using nine bullocks at different feeding levels. 
Table 2. Composition ( $\mathrm{g} / \mathrm{kg}$ ) of the concentrate mixtures given to bullocks during balance trials

\begin{tabular}{lccr} 
& \multicolumn{3}{c}{ Mixture } \\
\cline { 2 - 4 } Ingredients & $\mathrm{A}$ & $\mathbf{B}$ & $\mathrm{C}$ \\
Wheat bran & 674 & 774 & 874 \\
Groundnut cake (decorticated) & 270 & 170 & 70 \\
Mineral mixture* & 28 & 28 & 28 \\
Sodium chloride & 28 & 28 & 28 \\
DCP & 180 & 150 & 120 \\
ME $(\mathrm{MJ} / \mathrm{kg})$ & 10.01 & 9.93 & $9 \cdot 81$
\end{tabular}

DCP, digestible crude protein; ME, metabolizable energy; calculated from values reported by Sen $\&$ Ray ( 1964 ). ME has been calculated on the basis that I $\mathrm{g}$ total digestible nutrients contained $15.0995 \mathrm{~kJ}$ ME.

* The mineral mixture contained $(\mathrm{g} / \mathrm{kg})$ : calcium 236, phosphorus 114 , copper 1.8 , cobalt 0.3 , manganese $0 \cdot 5 \mathrm{I}$, iodine $\mathrm{I} \cdot 0$, sulphur, $7 \cdot 5$, iron $2 \cdot 4$, sodium chloride 300 .

\section{Diets}

Feeding-stuffs used were green berseem (Trifolium alexandrinum), oat straw (Avena sativa), Bengal gram husk (Cicer arietinum) and concentrate mixtures. Oat straw and gram husk were used only as energy sources, on the assumption that these foods contained no digestible crude protein (Sen \& Ray, 1964). The composition of the concentrate mixtures is given in Table 2 and the feeding regimen for the experimental animals in Table 3. Feeding was at $\mathbf{2} 2.00$ hours each day throughout the experimental period. Concentrates and gram husk were offered first, followed by roughages. Water was offered at $08.00, \mathrm{r} 3.00$ and $\mathrm{r} 8.00$ hours daily.

\section{Housing and management}

The bullocks were housed in a well-ventilated byre, spaciously partitioned with iron bars. During the collection period the animals were housed in metabolism stalls. All animals were weighed every 2 weeks and before and after each metabolism trial for 3 consecutive days. Weighings were done before the animals had any access to water or food.

\section{Analytical methods}

Faeces were collected manually and the urine was collected using collecting funnels held against the navel of the bullocks by means of rubber belts. Sampling of the faeces and urine was done every day at 07.30 hours. For nitrogen estimation, faeces were preserved in $5 \mathrm{ml} 18 \mathrm{M}$-sulphuric acid and the urine in $10 \mathrm{ml}$ concentrated sulphuric acid. For the estimation of energy, the urine sample was preserved with 1 ml potassium dichromate-mercuric chloride solution (Blaxter, Clapperton \& Martin, I966). The methods described by the Association of Official Agricultural Chemists (1960) were used to determine moisture, diethyl-ether extract, crude fibre and $N$ in food and faeces, except for the estimation of the moisture content of the faeces, when the method of Bratzler \& Swift (1959) was used. The energy content of the food, faeces and urine were estimated using a ballistic bomb calorimeter (A. Gallenkamp \& Co. Ltd, London). 
Table 3. Composition and daily intakes $(\mathrm{kg})$ of rations of bullocks during periods $\mathrm{x}-3$ * of balance trials

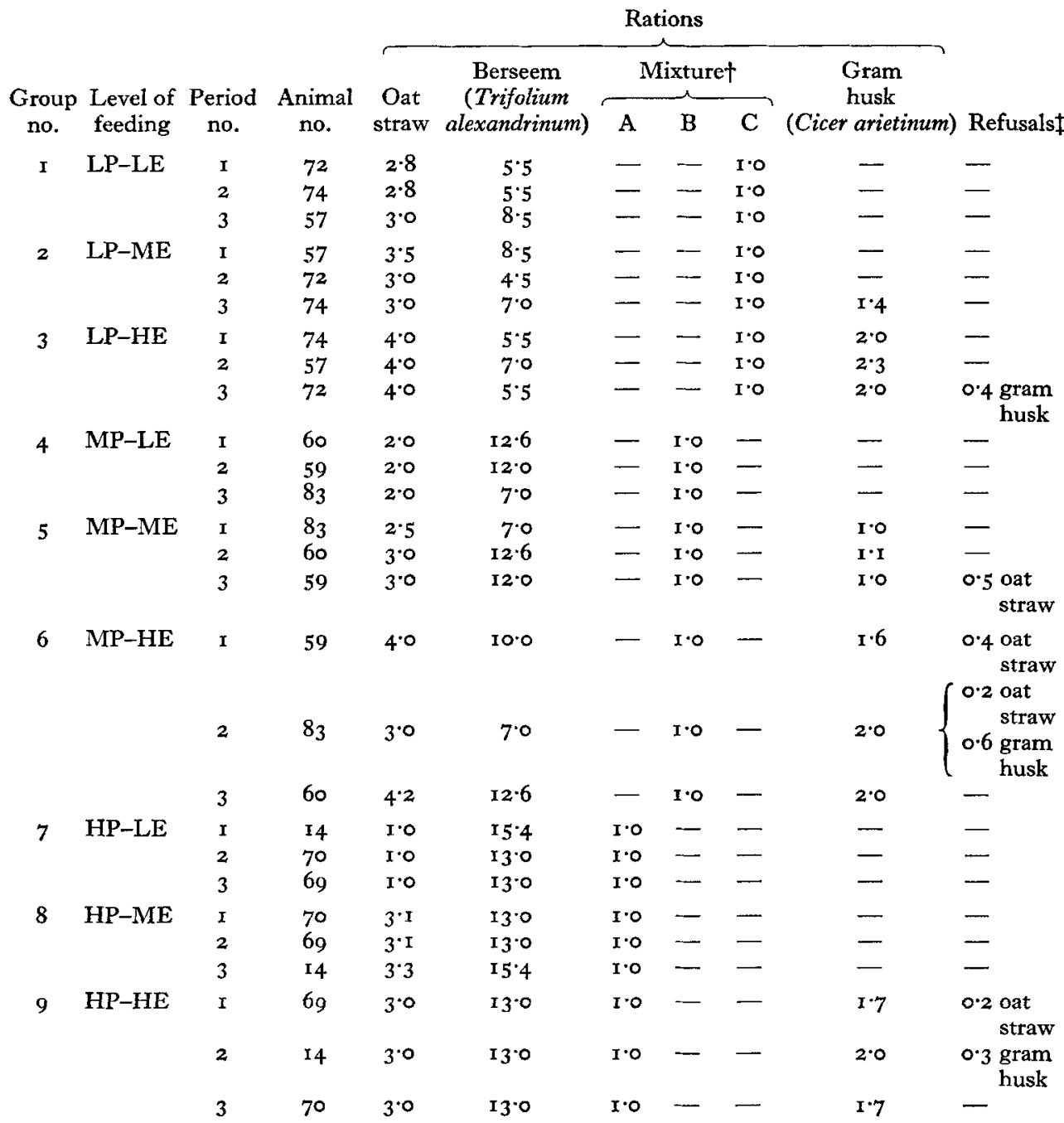

LP, low-protein; MP, medium-protein; HP, high-protein; LE, low-energy; ME, medium-energy; $\mathrm{HE}$, high-energy; representing 75,100 and $125 \%$ respectively of the digestible crude protein and metabolizable energy requirements recommended by the (US) National Research Council (I966). For details, see Table $\mathrm{I}$ and p. I 28 .

* For details, see Table $\mathrm{I}$; each period included $7 \mathrm{~d}$ adjustment, $2 \mathrm{I} \mathrm{d}$ preliminary, $7 \mathrm{~d}$ collection and $9 \mathrm{~d}$ respiration periods.

+ For details of composition, see Table 2.

$\ddagger$ Average values for $7 \mathrm{~d}$ collection period. 


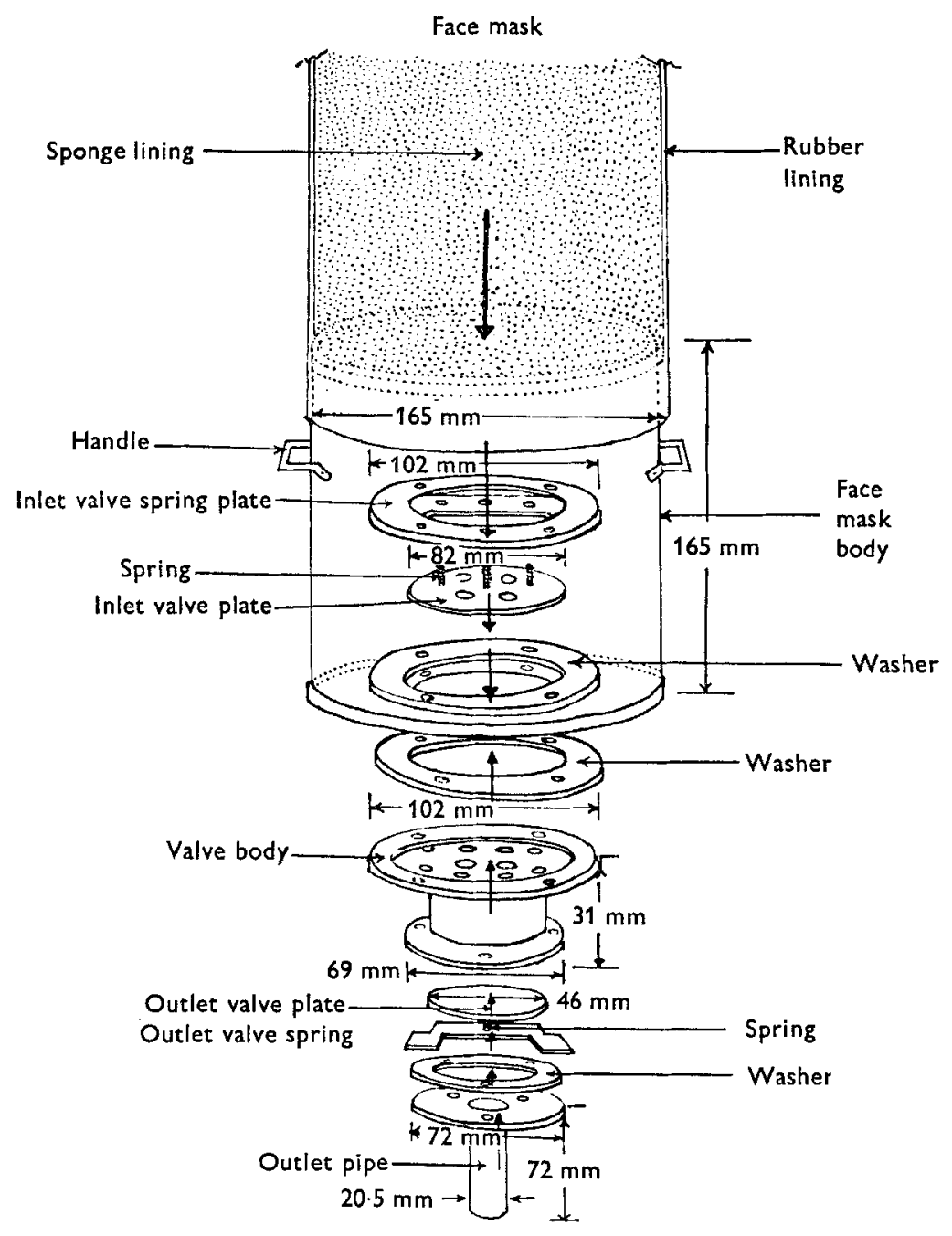

Fig. I. Diagrammatic representation of the face mask constructed for use with the open-circuit metabolism apparatus used to measure respiratory gases in balance trials using bullocks.

For each animal, the respiratory gas exchange was measured for 3 consecutive days at $09.00,15.00,18.00$ and 21.00 hours (i.e. 3, 6, 9 and $21 \mathrm{~h}$ after feeding). An open-circuit metabolism apparatus was used for respiratory measurements. During measurements air was inspired through the inlet valve and the body of the mask and was expired through the body of the mask and outlet valve to a 2001 Douglas bag (Daval Rubber Co., Philadelphia, USA). The face mask, which was constructed locally, is shown in Fig. I. The volume of the bag allowed the collection of the expired gas to be made for about 4-5 min. The expired gas volume was measured using a water-sealed gas meter as described by Shepherd (1955). The gas samples were analysed for carbon dioxide and oxygen content by the Haldane method (Brody, 
1968). Methane was estimated from the digested carbohydrates using the formula of Bratzler \& Forbes (1940): $\mathrm{E}=4^{\circ} \mathrm{0} \mathrm{I} 2 x+17^{.68}$; where $\mathrm{E}$ is methane produced $(\mathrm{g})$ and $x$ is carbohydrate digested $(\mathrm{g} \times \mathrm{I00})$. To obtain values for methane production in 1 the values were divided by 0.716 (Brouwer, 1965 ).

Heat production was calculated from the respiration results and urinary $\mathrm{N}$ excretion using the equation of Blaxter ( 1970$): \mathrm{H}=16 \cdot 18\left(\mathrm{O}_{2}\right)+5 \cdot 02\left(\mathrm{CO}_{2}\right)-2 \cdot 17\left(\mathrm{CH}_{4}\right)$ $-5.99(\mathrm{~N})$; where $\mathrm{H}$ is heat production $(\mathrm{kJ}) ;\left(\mathrm{O}_{2}\right)$ is oxygen consumption $(\mathrm{l}) ;\left(\mathrm{CO}_{2}\right)$ is carbon dioxide production (l); $\left(\mathrm{CH}_{4}\right)$ is methane production (l) and (N) is urinary nitrogen $(\mathrm{g})$.

The heat production values obtained at 3,6, 9 and $21 \mathrm{~h}$ after feeding were then averaged to represent daily heat production.

\section{RESULTS}

The average nutrient intakes per $\mathrm{d}$ and the live-weight changes per $\mathrm{d}$ for the various groups of bullocks are shown in Table 4 . The ME intake ranged from $333.6 \mathrm{~kJ} / \mathrm{kg}$ metabolic body size $\left(\mathrm{W}^{0.75}\right)$ per $\mathrm{d}$ in group HP-LE to $669.2 \mathrm{~kJ} / \mathrm{kg} \mathrm{W}^{0.75}$ per $\mathrm{d}$ in the LP-HE group. These values were 67.42 and $135.27 \%$, respectively, of the recommended standards of the (US) National Research Council (1966). The digestible crude protein intake ranged from $2.055 \mathrm{~g} / \mathrm{kg} \mathrm{W}^{0.75}$ per $\mathrm{d}$ in group LP-HE to $3.85 \mathrm{I} \mathrm{g} /$ $\mathrm{kg} \mathrm{W}^{0.75}$ per $\mathrm{d}$ in group HP-ME. These values were $72.42 \%$ and $135.75 \%$ of the recommended values of the (US) National Research Council (1966) respectively.

The energy balance results, with statistical analysis, are shown in Table 5. Losses of energy in faeces, methane and heat production and energy retention increased significantly $(P<0.01)$ as the level of energy in the diet increased. Protein level did not affect these losses significantly $(P>0.05)$. Loss of energy in the urine was not affected by either the energy or the protein level. Maximum energy retained and lost by the bullocks was $+\mathrm{r} 28.5$ and $-82.3 \mathrm{~kJ} / \mathrm{kg} \mathrm{W} \mathrm{W}^{0.75}$ per $\mathrm{d}$. Heat production ranged from $411^{1} 4 \mathrm{~kJ} / \mathrm{kg} \mathrm{W}^{0.75}$ per $\mathrm{d}$ in group MP-LE to $540.7 \mathrm{~kJ} / \mathrm{kg} \mathrm{W}^{0.75}$ per $\mathrm{d}$ in group LP-HE.

Regression lines were calculated to determine the relationships between $\mathrm{DE}$ and $\mathrm{ME}$ intakes and the energy retained on the basis of $\mathrm{kg} \mathrm{W}^{\mathbf{0 . 7 5}}$. As excess $\mathrm{N}$ causes a decrease in heat production and thus a decrease in energy retention of $30.55 \mathrm{~kJ} / \mathrm{g}$ excess $\mathrm{N}$ (Tyrrell, Moe \& Flatt, 1970), the heat production values were adjusted by subtracting $30.55 \mathrm{~kJ}$ for each $\mathrm{g}$ excess $\mathrm{N}$. The excess $\mathrm{N}$ intake was computed by subtracting the $\mathrm{N}$ required for maintenance from digestible $\mathrm{N}$ intake. The $\mathrm{N}$ required for maintenance was calculated by computing the regression of $\mathrm{N}$ balance $v$. digestible crude protein intake (Patle \& Mudgal, 1975). The regression equations are shown in Table 6 . Zero energy retention represented maintenance energy requirements. The existing points appeared to fit the regression line quite well. The correlation coefficients for energy balance $v$. DE, and $v$. ME intake, were 0.995 . This was highly significant. The maintenance energy requirements obtained by extrapolation of energy intake to zero energy retention yielded values of $539.43 \mathrm{~kJ} \mathrm{DE} / \mathrm{kg} \mathrm{W}^{0.75}$ per $\mathrm{d}$ and $448.8 \mathrm{IJ} \mathrm{kE} / \mathrm{kg} \mathrm{W^{0 \cdot 75 }}$ per d. 


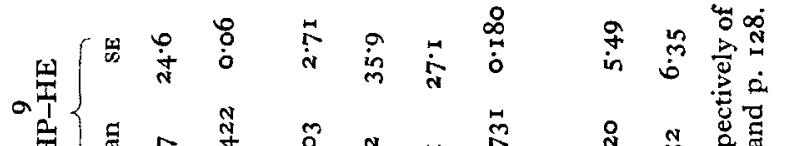

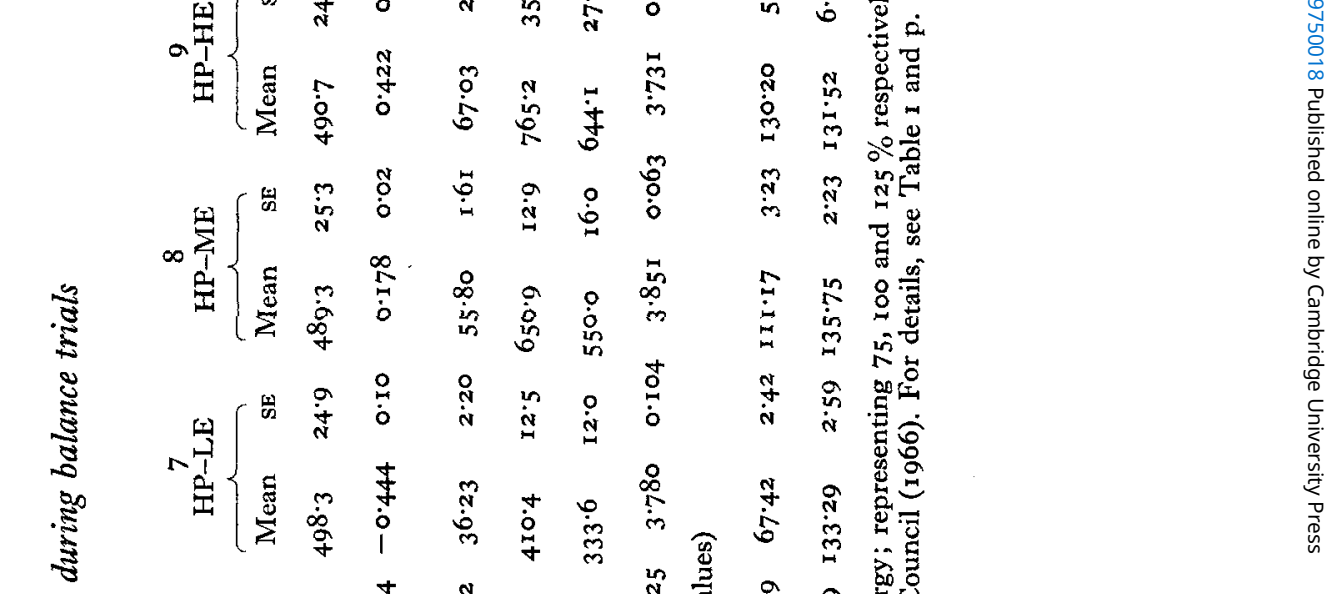

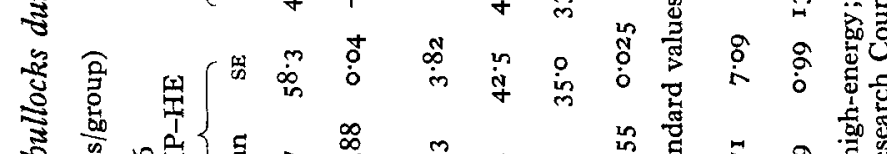

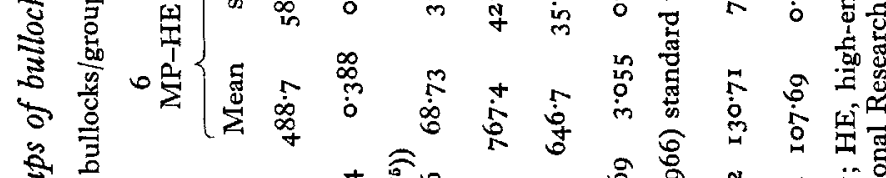

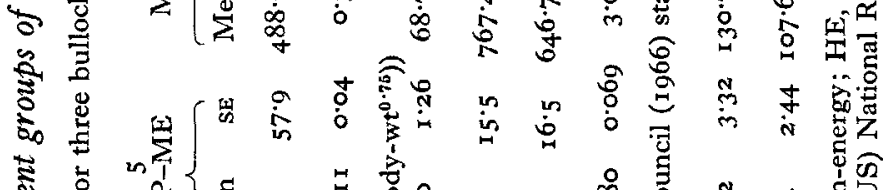

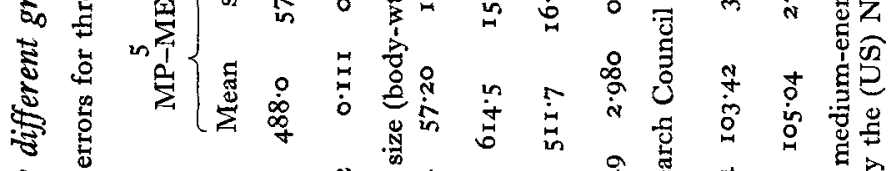

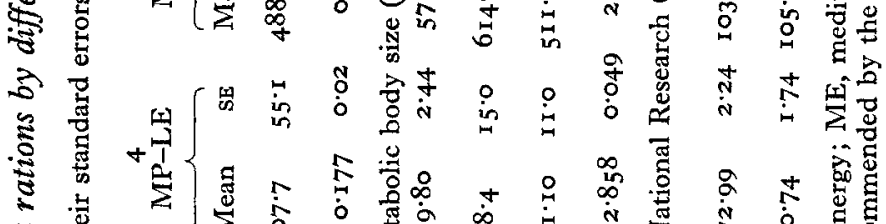

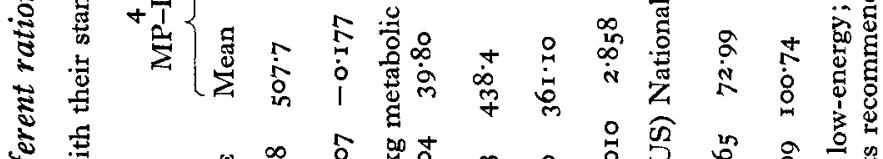

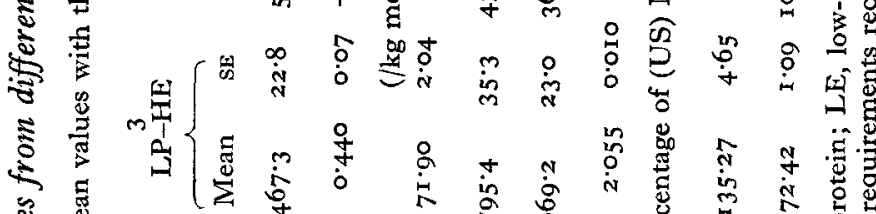

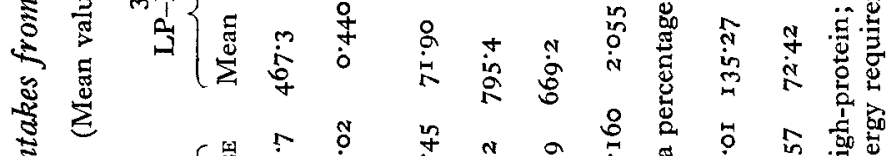

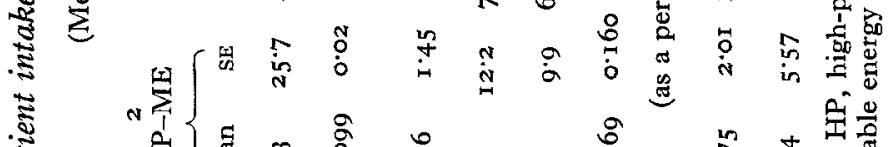

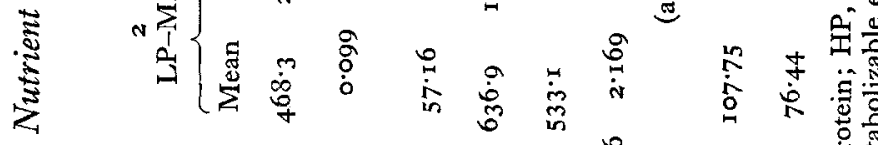

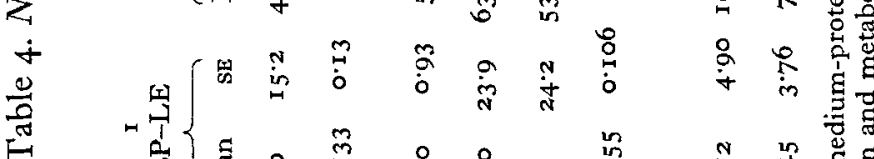

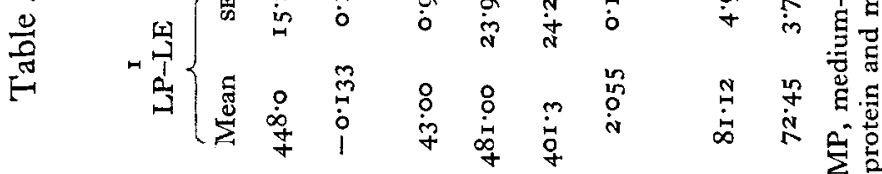

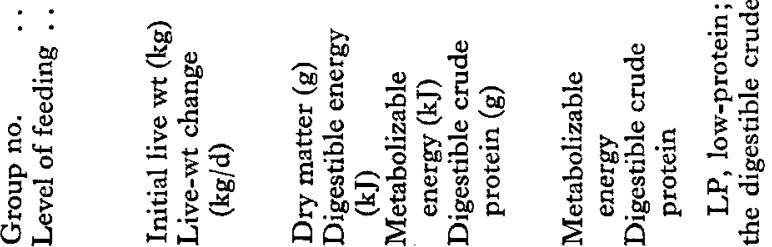




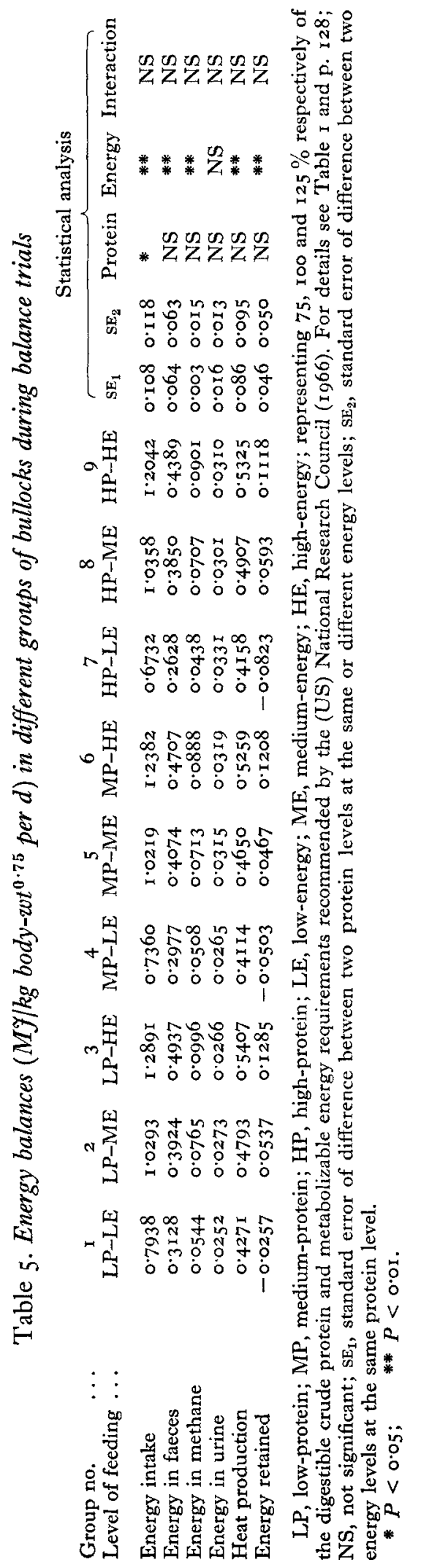


Table 6. Equations describing the relationship between daily energy intake and daily energy retention, and energy intake and heat production by bullocks

Linear equations

$$
\begin{aligned}
& \mathrm{EB}=0.5219 \mathrm{DE}-28 \mathrm{r} \cdot 53 \\
& \mathrm{~EB}=0.6019 \mathrm{ME}-270 \cdot \mathrm{I} 4 \\
& \mathrm{~EB}=0.8134 \mathrm{ME}-348.09 \\
& \mathrm{~EB}=0.5463 \mathrm{ME}-236.50 \\
& \mathrm{HP}=0.4016 \mathrm{ME}+268.33
\end{aligned}
$$

Multiple regressions

$$
\begin{aligned}
& \text { MEI }=0.425 \mathrm{MBS}+\mathrm{I} \cdot 835 \mathrm{EG}-\mathrm{I} \cdot 287 \mathrm{EL}+0.776 \\
& \mathrm{MEI}=0.373 \mathrm{MBS}-\mathrm{I} \cdot 072 \mathrm{EL}+4.7 \mathrm{I5} \\
& \mathrm{MEI}=0.429 \mathrm{MBS}+\mathrm{I} \cdot 818 \mathrm{EG}+0.5 \mathrm{II}
\end{aligned}
$$

Correlation
coefficient $(r)$
0.995 (all bullocks)
0.995 (all bullocks)
0.980 (bullocks in negative balance)
0.997 (bullocks in positive balance)
0.997 (all bullocks)
Multiple correlation
coefficient $(R)$
0.998 (all bullocks)
0.988 (bullocks in negative balance)
0.998 (bullocks in positive balance)

EB, Energy balance $\left(\mathrm{kJ} / \mathrm{kg}\right.$ body-wt $(\mathrm{W})^{0.75}$ per d); ME, metabolizable energy $\left(\mathrm{kJ} / \mathrm{kg} \mathrm{W}^{0 \cdot 75}\right.$ per d); MEI, metabolizable energy intake (MJ/d); EG, energy gain in the body (MJ/d); DE, digestible energy $\left(\mathrm{kJ} / \mathrm{kg} \mathrm{W} \mathrm{W}^{0.75}\right.$ per d); HP, heat production $\left(\mathrm{kJ} / \mathrm{kg} \mathrm{W}^{0.75}\right.$ per d); MBS, metabolic body size $(\mathrm{kg}) ; \mathrm{EL}$, energy loss from the body $(\mathrm{MJ} / \mathrm{d})$.

The ME requirement for maintenance was also computed by multiple regression using the following model:

$$
\mathrm{Y}=a+b_{1} \mathrm{X}_{1}+b_{2} \mathrm{X}_{2}+b_{3} \mathrm{X}_{3}
$$

where $\mathrm{Y}$ is $\mathrm{ME}$ intake corrected for excess $\mathrm{N}(\mathrm{MJ}) ; \mathrm{X}_{1}$ is $\mathrm{W}^{0.75}(\mathrm{~kg}) ; \mathrm{X}_{2}$ is energy retained in the body $(\mathrm{MJ})$ and $\mathrm{X}_{3}$ is energy lost from the body (MJ).

The energy gain or loss from the body are not separate measurements but are the arbitrary divisions of the energy balance results depending upon positive or negative energy balances. In this model, $b_{1}$ represents $\mathrm{ME}(\mathrm{MJ})$ required for maintenance $/ \mathrm{kg}$ $\mathrm{W}^{0.75}$ and $b_{2}$ represents $\mathrm{ME}(\mathrm{MJ})$ required for each $\mathrm{MJ}$ of tissue gain: $b_{3}$ represents ME (MJ) spared per MJ of body tissue loss. The constant ' $a$ ' represents the amount of ME which is not attributable to any specific variable in this model. This amount of energy was assigned to the maintenance term, as logically the normal turnover of the body stores should be attributed to the maintenance requirements (Moe, Tyrrell \& Flatt, 1970, 197I). This was done by dividing $a$ by average $\mathrm{W}^{0 \cdot 75}$ and adding it to the coefficient $b_{1}$. For bullocks in negative balance the adjustment was as follows: $0.373 \mathrm{I}+(+4.7 \mathrm{I} 5 \div 104.2 \mathrm{I})=0.41836 \mathrm{MJ}$. The reciprocal of $b_{2}$ represents the efficiency of utilization of ME for lipogenesis.

The multiple regression analysis of the ME intake by bullocks is shown also in Table 6. Separate regressions were computed for bullocks in negative balance, for bullocks in positive balance and for all bullocks: their maintenance energy requirements were $4 \mathrm{I} 8 \cdot 36,433.99$ and $43^{2} \cdot \mathrm{I}_{5} \mathrm{~kJ} \mathrm{ME} / \mathrm{kg} \mathrm{W}^{0 \cdot 75}$ per $\mathrm{d}$ respectively. The efficiency of utilization of ME as found by multiple regression was $55^{\circ} \mathrm{OI} \%$ for bullocks in positive energy balance and $55.4 \%$ for all bullocks.

Basal heat production or energy lost from the body at zero energy intake represents the net energy requirements for maintenance under idle conditions (Brody, I945; 
Table 7 . The daily maintenance energy requirements $(k f)$ of cattle and their composition, as obtained in the present experiment with some reported values

\begin{tabular}{|c|c|c|c|c|}
\hline \multirow[b]{2}{*}{ Source of values } & \multirow[b]{2}{*}{$\begin{array}{l}\text { Type of } \\
\text { cattle used }\end{array}$} & \multicolumn{3}{|c|}{$\begin{array}{l}\text { Requirement (per kg metabolic body size } \\
\left.\text { (body-wt } t^{0 \cdot 75}\right) \text { ) }\end{array}$} \\
\hline & & $\begin{array}{l}\text { Digestible } \\
\text { energy }\end{array}$ & $\begin{array}{l}\text { Metabolizable } \\
\text { energy }\end{array}$ & Net energy \\
\hline From present experiment & $\begin{array}{l}\text { Bullocks } \\
\text { (Brown Swiss } \times \\
\text { Sahiwal }\end{array}$ & $539 \cdot 43$ & $\left\{\begin{aligned} & 448 \cdot 8 \text { I } \text { (linear } \\
& \text { equation) } \\
& 432 \cdot \text { I } 5 \text { (multiple } \\
& \text { regression) }\end{aligned}\right.$ & 348.09 \\
\hline $\begin{array}{l}\text { Garrett, Meyer \& Lofgreen } \\
\text { (I959) } \\
\text { Hashizume, Kaishio, Ambo, } \\
\text { Tanaka, Hamada \& }\end{array}$ & Angus steers & $572 \cdot 51$ & $467 \cdot 04$ & $263 \cdot 65$ \\
\hline Takahashi ( $\left.196_{3}\right)$ & $\begin{array}{l}\text { Japanese black cows } \\
\text { Holstein cows }\end{array}$ & $\begin{array}{l}422 \cdot 73 \\
621 \cdot 39\end{array}$ & $\begin{array}{l}397 \cdot 32 \\
473 \cdot 62\end{array}$ & $\begin{array}{l}228 \cdot 25 \\
317 \cdot 01\end{array}$ \\
\hline $\begin{array}{l}\text { Flatt, Coppock \& Moore } \\
\quad(1965) \\
\text { Agricultural Research }\end{array}$ & Dry Holstein cows & - & $\begin{array}{l}439 \cdot 42,468 \cdot 72 \\
426 \cdot 87\end{array}$ & - \\
\hline $\begin{array}{l}\text { Council }(1965) \\
\text { (US) National Research }\end{array}$ & All cattle & - & $45 I \cdot 98$ & $334 \cdot 80$ \\
\hline Council (I966) & All cattle & $60 r \cdot 55$ & 49471 & - \\
\hline
\end{tabular}

Blaxter, 1962). Basal heat production may be estimated by extrapolation of the curve obtained by plotting heat production $v$. ME intake/kg W ${ }^{0.75}$ (Garrett, Meyer \& Lofgreen, 1959). The basal heat production of bullocks thus found was $268 \cdot 33 \mathrm{~kJ} / \mathrm{kg}$ $\mathrm{W}^{0.75}$ (equation 5 , Table 6). Knox, Crownover \& Wooden (1970) suggested that the basal metabolism could be obtained by plotting energy balance $v$. ME intake below maintenance, on a $\mathrm{W}^{0.75}$ basis. The theoretical fasting metabolism was $348.09 \mathrm{~kJ} / \mathrm{kg}$ $\mathrm{W}^{0.75}$ per d. The value for $b$ in equation 3 (Table 6) was 0.8134 , giving a value of $8 \mathrm{I} \cdot 34 \%$ for the efficiency of utilization of ME for maintenance.

Separate regression was also obtained by plotting energy balance $v$. ME intake above maintenance on a $W^{\mathbf{0 . 7 5}}$ basis. The value for $b$ in equation 4 (Table 6) was 0.5463 , a giving a value of $54.63 \%$ for the efficiency of utilization of ME for fat production.

\section{DISCUSSION}

The maintenance energy requirement obtained by multiple regression of $\mathrm{ME}$ intake was $43^{2} \cdot 15 \mathrm{~kJ} \mathrm{ME} / \mathrm{kg} \mathrm{W} \mathrm{W}^{0 \cdot 75}$ per $\mathrm{d}$, whereas the regression of energy balance $v$. ME intake on the basis of $W^{0.75}$ gave the value $44^{8.81} \mathrm{~kJ} \mathrm{ME} / \mathrm{kg} \mathrm{W}^{0.75}$ per $\mathrm{d}$. Brouwer, Van Es \& Nijkamp ( 1965 ) suggested that regression of energy retention $v$. ME intake might give inaccurate results as energy retention is computed from the difference between ME intake and heat production. Regression of heat production $v$. ME intake on the basis of $\mathrm{kg} \mathrm{W}^{0.75} / \mathrm{d}$ was, therefore, calculated. The amount of ME intake which caused an equal amount of heat production represented the ME requirement for maintenance. The value thus obtained was $448 \cdot 4 \mathrm{I} \mathrm{kJ} / \mathrm{kg} \mathrm{W}^{0 \cdot 75}$ per $\mathrm{d}$ which was not different from the value obtained by regression of energy balance $v$. ME intake.

For comparison a few published values for maintenance energy requirements have 
been presented in Table 7 . The maintenance energy requirements obtained for cross-bred bullocks in the present experiment were remarkably similar to those reported by Flatt, Coppock \& Moore (1965) and the Agricultural Research Council (1965) for European breeds of cattle. These values were slightly lower than those obtained by Garrett et al. (I959), Hashizume, Kaishio, Ambo, Tanaka, Hamada \& Takahashi $(1963)$ and those recommended by the (US) National Research Council (1966). However, in the present experiment the bullocks were restricted to stall feeding only, so the values for energy requirements obtained in this experiment represent only the minimum maintenance energy and do not include an allowance for activity. It may, in practice, be necessary to provide an extra allowance for grazing cattle.

Mullick \& Kehar (1952) suggested that Indian cattle required about $20 \%$ less energy than that recommended for European breeds of cattle. Mullick \& Kehar (1959) also estimated the resting metabolism of highland steers and reported that the resting metabolism for Indian breeds of cattle was lower than the resting metabolism for European breeds of cattle. The resting metabolism reported by Mullick \& Kehar (I959) was $17246 \mathrm{~kJ} / \mathrm{d}$ for a $133.0 \mathrm{~kg}$ steer, i.e. $449.89 \mathrm{~kJ} / \mathrm{kg} \mathrm{W} \mathrm{W}^{0.75}$ per d, which compares well with the ME requirements obtained by linear regression $(448.8 \mathrm{I} \mathrm{kJ} / \mathrm{kg}$ $\mathrm{W}^{0.75}$ per $\mathrm{d}$ ) in the present experiment. The former value is $90.97 \%$ of the standard value recommended by the (US) National Research Council (I966).

Regression of heat production $v$. ME intake on the basis of $W^{075}$ gave a value of $268.33 \mathrm{~kJ} / \mathrm{kg} \mathrm{W} \mathrm{W}^{0.75}$ per d, while extrapolation of the curve obtained by plotting energy balance $v$. ME intake below maintenance on the basis of $\mathrm{W}^{0.75}\left(\mathrm{~kJ} / \mathrm{kg} \mathrm{W}^{0.75}\right)$, gave the value $348.09 \mathrm{~kJ} / \mathrm{kg} \mathrm{W} \mathrm{W}^{0.75}$ per $\mathrm{d}$. The former value is similar to that $(273.82$ $\mathrm{kJ} / \mathrm{kg} \mathrm{W} \mathbf{W}^{0.75}$ per d), reported by Garrett et al. (1959) for Angus steers after extrapolating the curve of heat production $v$. ME intake. However, Flatt et al. (1965) found that there was a marked difference between the theoretical fasting metabolism values obtained by plotting heat production $v$. dry-matter intake (range $232 \cdot 3^{6-234} \cdot 3^{6} \mathrm{~kJ} / \mathrm{kg} \mathrm{W}^{0 \cdot 75}$ per d) and the actual fasting metabolism value (range $299.65-318.90 \mathrm{~kJ} / \mathrm{kg} \mathrm{W} \mathrm{W}^{0.75}$ per d). These authors have questioned the biological significance of such theoretical values.

Blaxter ( 1962 ) indicated that values for heat production of adult ruminants deviate considerably from the interspecific value of basal heat production of $292.95 \mathrm{~kJ} / \mathrm{kg}$ $\mathrm{W}^{0.75}$ per $\mathrm{d}$, values for sheep being lower by about $15 \%$ and those for cattle being higher by about I $5 \%$. The Agricultural Research Council (1965) summarized the published results and concluded that the fasting metabolism of mature steers produces about $334.80 \mathrm{~kJ} / \mathrm{kg} \mathrm{W}^{0.75}$ per $\mathrm{d}$. This is in agreement with the fasting metabolism value of $348.09 \mathrm{~kJ} / \mathrm{kg} \mathrm{W}^{0.75}$ per $\mathrm{d}$, obtained by plotting energy balance $v$. ME intake below maintenance on the basis of $\mathrm{kg} \mathrm{W}^{0.75}$ in the present studies.

The ME requirement for maintenance could also be calculated using fasting metabolism and the efficiency of utilization of $\mathrm{ME}$ for maintenance values (equation 3, Table 6). The ME requirement for maintenance thus obtained was $100 \div 8 \mathrm{r} \cdot 34=$ $\mathrm{r} .23 \times 348.09=428.15 \mathrm{~kJ} \mathrm{ME} / \mathrm{kg} \mathrm{W} \mathrm{W}^{0.75}$ per $\mathrm{d}$. This value is similar to the value $432 \cdot 15 \mathrm{~kJ} \mathrm{ME} / \mathrm{kg} \mathrm{W}^{0.75}$ per $\mathrm{d}$, obtained by multiple regression in the present studies. 
The calculation shows that a reliable estimate of fasting heat production could be obtained by extrapolation of the curve obtained by plotting energy balances $v$. ME intake below maintenance on the basis of $\mathrm{kg} \mathrm{W}^{0 \cdot 75}$.

The summary prepared by the Agricultural Research Council (1965) shows that cattle and sheep, on average, utilize the $\mathrm{ME}$ of food for maintenance with an efficiency of about $74 \%$ : Flatt et al. (1965) found the efficiency of utilization of ME for maintenance of cattle was $79.0 \%$. These values are similar to that $(8 \mathrm{r} \cdot 34 \%)$ obtained in the present experiment.

The regression analysis of the energy balance $v$. ME intake above maintenance gave an efficiency of $54.63 \%$ (equation 4 , Table 6 ) for lipogenesis. The multiple regression analysis of $M E$ intake also gave a similar value $(\mathrm{I} \div \mathrm{I} \cdot 835=54.50 \%$, equation 9 , Table 6) for lipogenesis; Flatt et al. (1965) reported a value of $50 \%$ and Moe et al. (1970), $58.7 \%$.

The regression of energy balance $v$. ME intake below maintenance was significantly $(P<0.01)$ different from that of energy balance $v$. ME intake above maintenance, indicating that the efficiency of utilization of ME for maintenance was significantly $(P<0.01)$ different from, and was higher than, that for lipogenesis. This is in agreement with the results obtained by Flatt et al. (I965). Similarly, Greenhalgh ( 1969 ) reviewing the literature, concluded that the average efficiency of utilization of ME for maintenance was $74 \%$, whereas that for lipogenesis ranged from $43 \%$ for a ration containing $9.2 \mathrm{MJ} \mathrm{ME} / \mathrm{kg}$ to $62 \%$ for a ration containing $13.4 \mathrm{MJ} \mathrm{ME} / \mathrm{kg}$. The lower utilization of ME for lipogenesis than for maintenance may be due to the lower efficiency of lipogenesis as compared to that of reactions involved in maintenance.

The authors are grateful to Dr D. Sundaresan, Director, National Dairy Research Institute, Karnal, and Dr P. G. Nair, formerly Dairy Husbandry Officer, now Principle, Dairy Science College, for their keen interest and for providing facilities; the ICAR for granting a senior fellowship to B.R.P., and Dr H. K. Parekh, Associate Professor of Animal Husbandry, JNKVV, Jabalpur, for advice on the statistical analysis of the results.

\section{REFERENCES}

Agricultural Research Council (1965). The Nutrient Requirements of Farm Livestock No. 2, Ruminants. London: Agricultural Research Council.

Association of Official Agricultural Chemists (1960). Official Methods of Analysis gth ed. Washington, DC: Association of Official Agricultural Chemists.

Blaxter, K. L. (1962). The Energy Metabolism of Ruminants. London: Hutchinson and Co.

Blaxter, K. L. (1970). Publs Eur. Ass. Anim. Prod. no. 13, p. 14.

Blaxter, K. L., Clapperton, J. L. \& Martin, A. K. (1966). Br. F. Nutr. 20, 449.

Bratzler, J. W. \& Forbes, E. B. (1940). F. Nutr. 19, 611 .

Bratzler, J. W. \& Swift, R. W. (1959). J. Dairy Sci. 42, 686.

Brody, S. (1945). Bioenergetics and Growth. New York: Reinhold Publishing Corp.

Brody, S. (1968). Bioenergetics and Growth p. 338. New York: Hafner Publishing Co. Inc.

Brouwer, E. (1965). Publs Eur. Ass. Anim. Prod. no. I1, p. 441.

Brouwer, E., Van Es, A. J. H. \& Nijkamp, H. J. (1965). Publs Eur. Ass. Anim. Prod. no. 11, p. 205.

Flatt, W. P., Coppock, C. E. \& Moore, L. A. (1965). Publs Eur. Ass. Anim. Prod. no. Ir, p. 131.

Garrett, W. N., Meyer, J. H. \& Lofgreen, G. P. (1959). F. Anim. Sci. 18, 528. 
Gopal Krishna (1971). Studies on energy and protein requirements for milk production in Indian dairy animals. PhD Thesis, Agra University, India.

Greenhalgh, J. F. D. (1969). International Encyclopaedia of Food and Nutrition Vol. I7, Part 2. Oxford: Pergamon Press.

Hashizume, T., Kaishio, Y., Ambo, S., Tanaka, K., Hamada, T. \& Takahashi, S. (I963). Nutr. Abstr. Rev. 33, 242 Abstr.

Knox, K. L., Crownover, J. C. \& Wooden, G. R. (1970). Publs Eur. Ass. Anim. Prod. no. r3, p. I8r.

Moe, P. W., Tyrrell, H. F. \& Flatt, W. P. (1970). Publs Eur. Ass. Anim. Prod. no. 13, p. 65.

Moe, P. W., Tyrrell, H. F. \& Flatt, W. P. (1971). F. Dairy Sci. 54, 548.

Mudgal, V. D. (1963). Studies on the growth and age of maturity of Tharparkar, Sahiwal and Red Sindhi calves. PhD Thesis, Agra University, India.

Mudgal, V. D. (1969). Review of Work Carried Out in Animal Nutrition in Southern Regional Station. Bangalore: National Dairy Research Institute.

Mullick, D. N. (1959a). Indian F. Physiol. all. Sci. 13, 52.

Mullick, D. N. (1959b). Indian F. Physiol. all. Sci. 13, I07.

Mullick, D. N. \& Kehar, N. D. (1952). Proc. Indian Sci. Congr. Part 3, p. 266.

Mullick, D. N. \& Kehar, N. D. (1959). Indian F. vet. Sci. 29, 27.

National Research Council (1966). Nutrient Requirements of Domestic Animals No. 3, Nutrient Requirements of Dairy Cattle. Washington, DC: National Research Council.

Patle, B. R. \& Mudgal, V. D. (I975). Indian F. Dairy Sci. 28. (In the Press.)

Sen, K. C. \& Ray, S. N. (1964). Bull. Indian Coun. agric. Res. no. 25.

Shepherd, R. F. (1955). F. Physiol., Lond. 127, 6r 5.

Tyrrell, H. F., Moe, P. W. \& Flatt, W. P. (1970). Publs Eur. Ass. Anim. Prod. no. 13, p. 69. 